\title{
ケアハウス居住者の生活展開と生活領域の拡がりに関する研究 A STUDY ON THE RELATIONSHIPS BETWEEN BEHAVIOR AND TERRITORIES OF ELDERLY IN "CARE HOUSES"
}

\author{
伊佐地 大輔*, 上野 淳** \\ Daisuke ISAJI and Jun UENO
}

\begin{abstract}
The aim of this paper is to clarify the expansion of activities and living territory held at each space of elderly inhabitants of "Care House". The results of the analysis are as follows.

1)The place formed by various activities in room were fully understood and classified. 2)Features of living activity related with programs held at common space and other activities were clarified.

3) To act in outer space, inhabitants choose each facility and place. The effects to those acts and territories by environments of location were recognized. 4)Features of expanding territories were differ by each acts, seemed they had four qualities;staginess, selectivity, development and attachment. Points written above classified whole activities.
\end{abstract}

keywords : Care House, The Elderly, Behavioral Environment, Activities of daily life, Living Teritory ケアハウス, 高齢者, 行為環境, 生活展開, 生活領域

1. はじめに

\section{1. 研究の背景と目的人口高龄化の進展に対応して, 高制者施} 設の量的・質的充足に向け，様々な施策が展開されている。この中 でケアハウスは，一定の身体機能の低下があるものの，ある程度自 立的な生活が可能な高㱓者がスタッフの生活サポートのもとに集 まって居住する集住の形式であり，施設処遇から在宅処遇へと施策 の重点をシフトしようとする全体的な傾向の中で，今後，重要な位 膡を占めるものと考えられる.1989 年に経費老人ホームのC型とし て初めて位置づけられ，ゴールドプラン 21 では 10.5 万人分の 整備が目標とされている。ケアハウスの制度概要を表 1 に表す。 サービスやサポートの構成を整理すると以下のようになる。1) 生活 基礎（食事・入浴）については施設サービスを利用.2）生活支援に ついてはスタッフの生活サポートをうけ, 介護・援助は外部の在宅 サービスを利用。3) 生きがい等については施設の共用空間や外部の 施設を利用。このように居住者は，施設側からサポートをうけつつ， 共用空間や外部空間を利用することにより，個々の身体状況にあわ せ，自立した生活を過ごすことが目標とされる。

こういった背景を踏まえると，ケアハウスを計画する際には，居 住者個々人の身体状況や加齢に対応し自立した活動を支えていく環 境を整えると共に，地域活動を念頭においた立地環境を重視するこ
とも大切になってくると考えられる。そこで, 本研究ではケアハウ スを施設単体として捉えるのではなく，1）居室・共用空間・外部 （地域）空間と連続する行為環境の場して捉え，この各段階の連続 性の中で生活実態を詳細に把握することにより，居住者の生活構造 を解明していくこと，更に，2）高龄者個人の生活にとって，また， それぞれの行為にとって, 各空間がどのように意味づけられている かを考察していくこと，を目的としている。これらにより，住まい の場（住宅）として地域社会における活動を主としつつも, 自立し た生活を可能とするケアハウスのあり方を探っていこうとするもの である.

\begin{tabular}{|c|c|}
\hline 刘象者 & 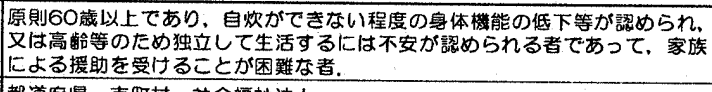 \\
\hline |閶設者 & 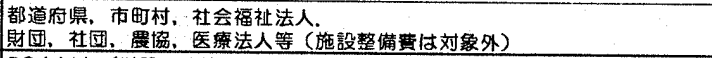 \\
\hline 定㝠 & 30人以上（併設の塂合は15人以上） \\
\hline \begin{tabular}{|l} 
スタッフ \\
配置 \\
\end{tabular} & 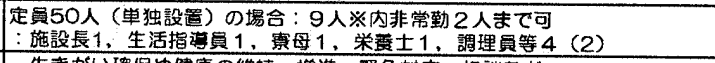 \\
\hline サービス & 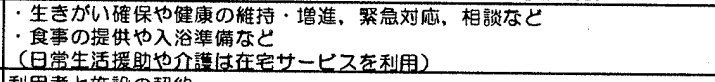 \\
\hline 利用方法 & 利用者と施設の契約 \\
\hline 貫用 & 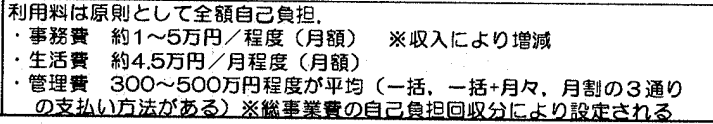 \\
\hline
\end{tabular}

\footnotetext{
* 東京都立大学大学院 大学院生 - 修士 (工学)

** 東京都立大学大学院 教授.工博
}

Graduate Student, School of Architecture, Graduate School of Engineering, Tokyo Metropolitan Univ., M. Eng.

Prof., School of Architecture, Graduate School of Engineering, Tokyo Metropolitan Univ., Dr. Eng. 
ケアハウスに関する既往研究をみると，小川(1995) らは，施設夕 イプの分類, 入居者の属性, 入居による余层の過ごし方や外出頻度 の変化を把握し(文1), 森永（1996）らは入居理由や入居前後の住宅 実態を把握し転居のプロセスについての把握を行っている(文2)。し かし, 本研究のように高龄者の日常生活の実態を詳細に捉え, 施設 空間だけでなく外部（地域）空間も含んだ生活領域の拡がりを捉え ること, また，各空間における生活展開の詳細を把握するなかから， それぞれの空間が持つ意味づけを把握していくこと, などは充分に はなされていないと考えられる。施設整備は進んできたとはいえ， 建築計画学の分野におけるケアハウス研究の蓄積は, 特別養護老人 ホームをはじめとする福祉施設研究に比べて充分なものとはいえ ず，その評価は定まっていないと考える。

1.2. 研究の方法本研究では, ケアハウス居住者の生活像を捉え るのにあたり，その立地条件（周辺ら地域環境）や施設内の共用空 間の設け方 (平面構成) の違いを考慮することが必要になってくる。 そこで, 本研究では平面構成および立地環境において, それぞれ特 徵をもつケアハウス 3 施設を調查対象として取り上げている(表 2 , 図 1). H 12 年 9 月〜 12 月にかけて, (1)居住者属性調查, (2)施設内 1 日の観察調查, (3)居住者の活動行為と活動場所についてのアン ケート・ヒヤリング調查, (4)居室内の実測調查, (5)スタッフへのヒ ヤリング調查，を行った，調査の概要を表 3 にまとめる。本稿の 構成は，2 章で居住者個人の生活展開の全体像, 生活領域の拡がり の概要を捉え， 3，4，5章で住戸(自室) ・(施設内）共用空間。 外部空間（地域空間）の各領域段階において，居住者がどの様に生 活を展開しているかについて考察を行っている。これらを踏まえ，
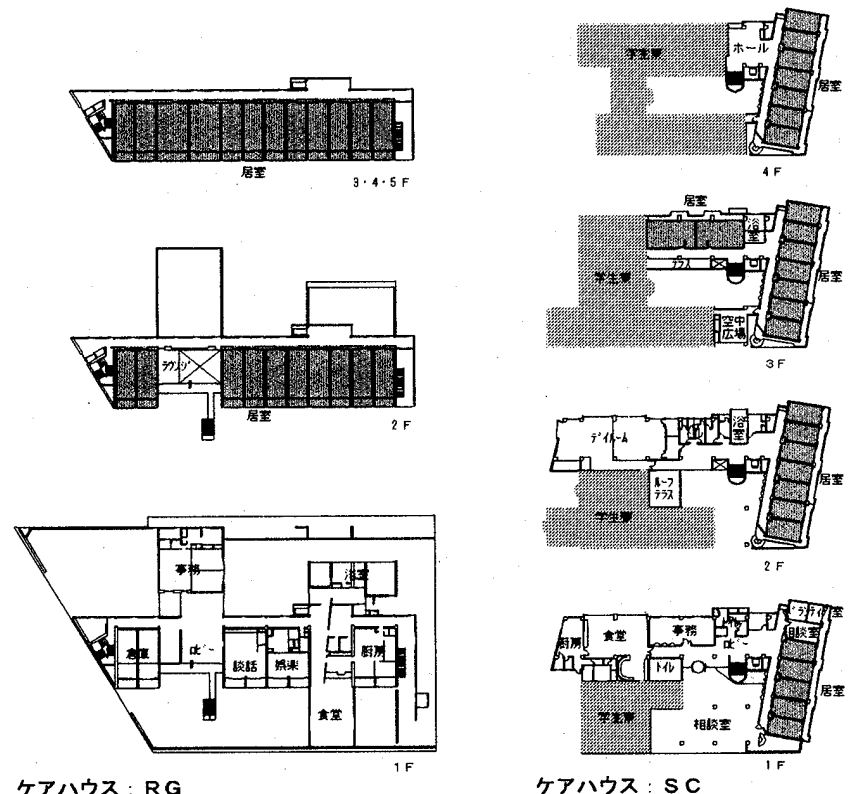

ケアハウス : RG

ケアハウス：SC

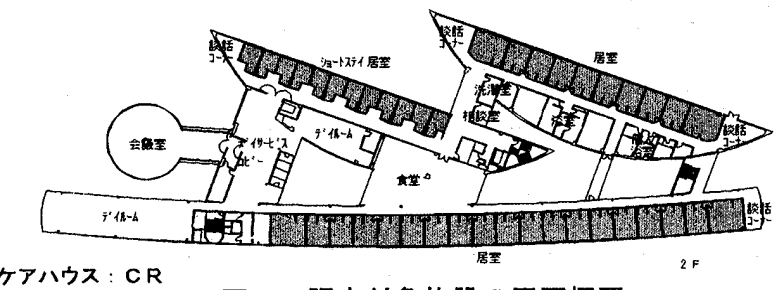

図 1 調査対象施設の平面概要

\begin{tabular}{|c|c|c|c|}
\hline & ケアハウス:RG & ケアハワス:SC & ケアハウス:CR \\
\hline 酎在地 & 埼玉戛越谷市 & 宩京都武藏野市 & 培丙県志本市 \\
\hline 開設年 & H11.4 & 148.6 & H.9.4 \\
\hline 居空棈成 & $\begin{array}{l}\text { 笚身 } 38 \bar{P} \\
\text { 夫䀦 } 6 \overline{\bar{P}}\end{array}$ & $\begin{array}{ll}\text { 单身 } 26 \bar{P} \\
\text { 夫壃 } 2 \bar{P}\end{array}$ & 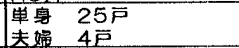 \\
\hline & 洽室なし & 浴室あり & 溶垔なし \\
\hline 平面满掝 & 2喝，片廊下型 & 2㰾，片廊下型 & 1畠。回廊型 \\
\hline $\begin{array}{l}\text { 共用空間 } \\
\text { 配置 }\end{array}$ & $\begin{array}{l}\text { 1Fに諸空を集中して配 } \\
\text { 萣，郎下端につーナー }\end{array}$ & 各階に分散配置 & $\begin{array}{l}\text { 食堂を中心に分散配要 } \\
\text { 醀下端にJーナ一- }\end{array}$ \\
\hline 立地 & $\begin{array}{l}\text { 駅への川ス便は少ない } \\
\text { 周辺地城は商店が1つ } \\
\text { あるだけ。前面道路は } \\
\text { 幹線道路であり。散策 } \\
\text { には適さない. }\end{array}$ & 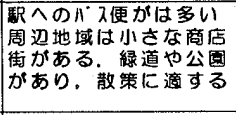 & 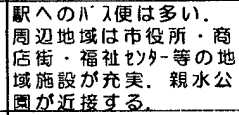 \\
\hline 併設機能 & 単独型 & 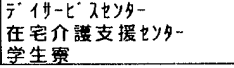 & 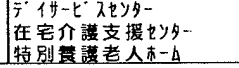 \\
\hline
\end{tabular}

表 3 调查概要

\begin{tabular}{|c|c|}
\hline 1. スタッフヘの & 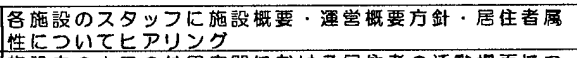 \\
\hline 2. 施設内行動観察拥查 & \begin{tabular}{|l|} 
施設内の1日の其用空間 \\
いて图面上に記䤸。
\end{tabular} \\
\hline $\begin{array}{l}\text { 3. 居住者に刘するアン } \\
\text { ケート・ヒアリング } \\
\text { 調雷 }\end{array}$ & 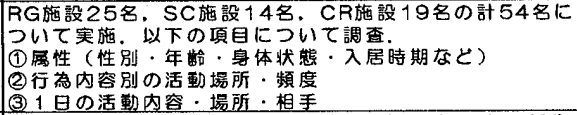 \\
\hline 4. 居室实測調查 & 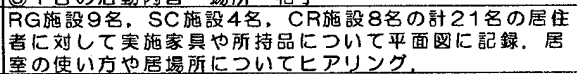 \\
\hline
\end{tabular}

表 4 居住者属性

\begin{tabular}{|c|c|c|c|c|c|c|c|}
\hline \multirow{3}{*}{\multicolumn{2}{|c|}{ 入居者数/定買 }} & \multirow{2}{*}{\multicolumn{2}{|c|}{$\begin{array}{c}\text { ケPハウス:RG } \\
42 / 50\end{array}$}} & \multirow{2}{*}{\multicolumn{2}{|c|}{$\frac{\text { ケアハウス:SC }}{29 / 30}$}} & \multirow{2}{*}{\multicolumn{2}{|c|}{$\frac{\text { ケアハウス:CR }}{33 / 33}$}} \\
\hline & & & & & & & \\
\hline & & 8 & $190 \%$ & 6 & $20.7 \%$ & 6 & $18.2 \%$ \\
\hline & 女 & 34 & $84.0 \%$ & 23 & $79.3 \%$ & 27 & $81.8 \%$ \\
\hline \multirow{6}{*}{ 年解 } & \begin{tabular}{|l|}
$\sim 64$ \\
$65 \sim 6$
\end{tabular} & $\frac{2}{2}$ & $\begin{array}{r}4.8 \% \\
4.8 \% \\
\end{array}$ & 1 & $\frac{3.4 \%}{0.0 \%}$ & 0 & $\begin{array}{l}0.0 \% \\
0.0 \%\end{array}$ \\
\hline & $70 \sim 74$ & 11 & $26.2 \%$ & 6 & $20.7 \%$ & 2 & $6.1 \%$ \\
\hline & $75 \sim 79$ & 11 & $26.2 \%$ & 3 & $10.3 \%$ & $\overline{9}$ & $273 \%$ \\
\hline & $80 \sim 84$ & 13 & $310 \%$ & 9 & $31.0 \%$ & 9 & $27.3 \%$ \\
\hline & $85 \sim 89$ & 1 & $24 \%$ & 8 & $27.6 \%$ & 8 & $242 \%$ \\
\hline & $90 \sim$ & 2 & $4.8 \%$ & 2 & $6.4 \%$ & 8 & $15.2 \%$ \\
\hline \multirow{7}{*}{ 要介護度 } & 平均 & $\frac{77}{10}$ & $952 \%$ & $\frac{80}{18}$ & $\frac{6}{62.1 \%}$ & $\frac{82}{20}$ & $606 \%$ \\
\hline & $\begin{array}{l}\text { क人U } \\
\text { 要支援 }\end{array}$ & 1 & $24 \%$ & 2 & $6.9 \%$ & 6 & $18.2 \%$ \\
\hline & 要介護I & 0 & $0.0 \%$ & 5 & $17.2 \%$ & 4 & $12.1 \%$ \\
\hline & 要介盅II & 1. & $24 \%$ & 3 & $10.3 \%$ & 2 & $6.1 \%$ \\
\hline & 要介讙亚 & 0 & $0.0 \%$ & 1 & $3.4 \%$ & 0 & $0.0 \%$ \\
\hline & 要介護IV & 0 & $0.0 \%$ & 0 & $0.0 \%$ & 1 & $3.0 \%$ \\
\hline & 要介護V & 0 & $0.0 \%$ & 0 & $0.0 \%$ & 0 & $0.0 \%$ \\
\hline \multirow{4}{*}{ 移動手段 } & 歩行司 & 38 & $90.5 \%$ & 19 & $65.5 \%$ & 25 & $75.8 \%$ \\
\hline & 杖 & 3 & $7.1 \%$ & 5 & $17.2 \%$ & 4 & $12.1 \%$ \\
\hline & 步行器 & 0 & $0.0 \%$ & 3 & $10.3 \%$ & 3 & $9.1 \%$ \\
\hline & 重椅子 & 1 & $2,4 \%$ & 2 & $6.9 \%$ & 1 & $3.0 \%$ \\
\hline \multirow{4}{*}{ 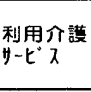 } & $\hbar-A \wedge N n^{\circ}-$ & 2 & $4.8 \%$ & 11. & $37.9 \%$ & 12 & $36.4 \%$ \\
\hline & $=1+1+-t^{\prime} \lambda$ & 2 & $4.8 \%$ & 4 & $13.8 \%$ & 7 & $21.2 \%$ \\
\hline & シ外远1 & 0 & $0.0 \%$ & 1. & $3.4 \%$ & 은 & $0.0 \%$ \\
\hline & 訪問看讙 & 0 & $0,0 \%$ & 0 & $0.0 \%$ & 1. & $3.0 \%$ \\
\hline \multirow{5}{*}{ 居住期閪 } & $\sim 6 \tau$ 目 & 1 & $40 \%$ & 0 & $0.0 \%$ & 1 & $5.3 \%$ \\
\hline & $6 \tau$ 月 1 年 & 6 & $24.0 \%$ & 1 & $7.1 \%$ & 3 & $15.8 \%$ \\
\hline & 1年 2 年 & 18 & $72.0 \%$ & 1. & $7.1 \%$ & 4 & $21.1 \%$ \\
\hline & 2年 3年 & 0 & $0.0 \%$ & 3 & $21.4 \%$ & 3 & $15.8 \%$ \\
\hline & 3年 5年 & 0 & $0.0 \%$ & 9 & $64.3 \%$ & 8 & $42.1 \%$ \\
\hline
\end{tabular}

6 章で各行為における空間の拡がりの考察を行っている.

1.3. 居住者属性調查対象者の属性を表 4 に示す. 入居条件よ り, 自立している高龄者が中心となっているものの, 特別養護老人 ホームに移り住むまでの期間を住まう居住者も存在する．このた め, 要介護度の分布をみると $[$ な $]$ から [ 要支援 $],[$ 要介護IV $]$ まで みられるなど, 居住者の属性は多様である. 施設別にみると, R G 施設は年齢，要介護度ともに低く，自立高齢者中心である，SC施 設は開設から 4 年以上が経過しており継続居住者が多いためか, 要介護度も相対的に高くなっている，CR施設は年齢は高いが， 自立した高龄者が多いのが特徵である。

\section{2. 生活展開と生活領域の拡がり}

居住者の生活は，住戸，共用空間，外部空間のそれぞれで閉じて いるのではなく, 生活展開は連続性を持ち, かっ, 相互に関連性を 持っている。以下では, 調査(3)より得られたデータをもとに, 生活 領域を住戸・共用空間・外部空間に分け，1日の生活や行為がそれ ぞれの領域においてどのように展開されているかについて，その概 
要, 全体像を把握しようとする。

2.1. ケアハウス居住者の 1 日の生活展開の事例 生活領域の拡が りを具体的に表すため，居住者の 1 日における特徴的及び典型的な 生活展開事例（図 2 ） 4 例示す. [ 事例 1 ] は食事・入浴のプログラ ム以外の時間を自室内で過ごし，T VやCD等の静的活動を中心に 1 日を過ごしているケースである. [ 事例 2] では施設内の友人との 交流が頻繁に行われており，食堂や友達の部屋から外部空間にまで 領域が拡がっていく様子がみられる.[事例 3 ] では前者と同様に施 設内での交流活動が行われているが, 共用諸室でのサ一クル活動が 主となっている. [事例 4]では數地周辺や周辺地域における趣味・交 流活動を主とする事例である。このように個人の生活展開は多様で あり，生活領域の拡がりについても幾つかの特徵がみられる。

1 日における生活場所を住戸・共用空間・外部空間に分類し，そ の 1 人 1 人の時間内訳の分布を図 3 に示した. 注1) 全体的には自室 内での生活が中心であるが，共用空閒・外部空間への分布の拡がり がみられ，居住者がそれぞれに諸空間を使いこなしている様子が伺 える. 次に，年跉構成との関係で生活領域の使い分けをみると（全 調查対象者年齢階層別平均），加齢により，自室内における活動が 増加し，外部空間での活動が減少する傾向がみられる（図 4). 対 して，共用空間での活動は，加龄による変化はあまりみられない。 これらは加齢に対する共用空間の有用性として捉えることができる。

\section{2. 生活行為の種類と生活領域の拡がり 次に，居住者の生活行} 為の内容についてみる. 本調查により把握された生活行為について 整理し，NHK 国民生活時間調查の行動分類を参考に，表 5 のように 分類した. 分類された各行為別の拡がりの様子を表すため, 各空間 における行為人数割合を表 6 に整理した. 注2)これより，睡眠，買 い物のようにある空間でのみ行われる行為, 食事や入浴のようにあ る空間で行われるが他の空間でも行うことがある行為，また，趣味，
運動など余㖊活動や交流のように各空間に拡がって行われる行為な ぞ, 各行為内容により，それぞれの空間の拡がりの特徴がみられた。

\section{3. 住戸空間の使われ方}

調查(3)に加え, 調查(4)で 21 名の居住者に対して, 住戸内の家具 や所持品の実測調查を行った。表 7 に調查(4)の居室実測調查の概要

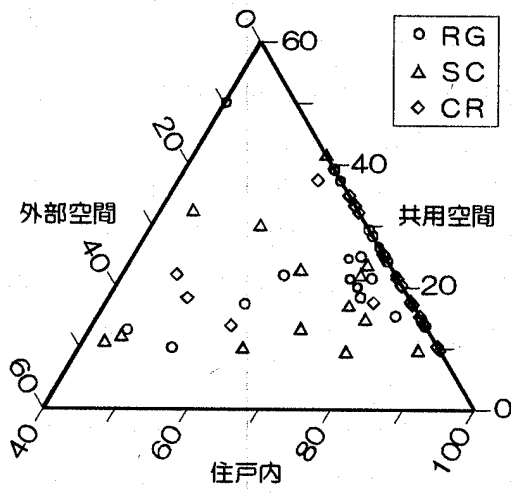

図3生活場所別滞在時間 内訳の分布

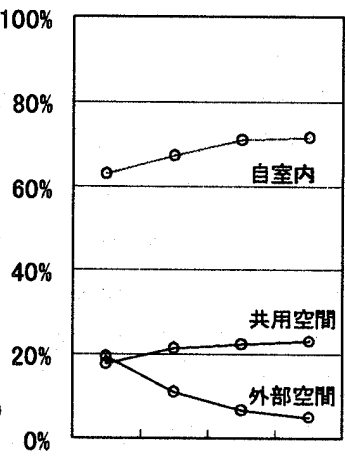

60 代 70 代 80 代 90 代

図 4 生活場所別滞在時間 内訳の年龄別平均

\section{表 5 生活行為の分類}

\begin{tabular}{|c|c|c|c|c|c|}
\hline 太分䅡 & 中分矤 & 細分類 & 太分類 & & \multirow{3}{*}{ 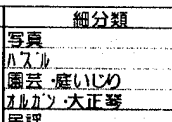 } \\
\hline 基本的生活 & 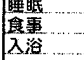 & 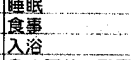 & \multirow{7}{*}{ 余睱活動 } & & \\
\hline & 誰事 & 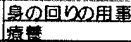 & & & \\
\hline 䚢的活動 & 能的 & 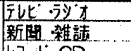 & & & 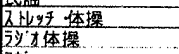 \\
\hline & & 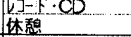 & & 運動 & 毁 \\
\hline 社会活勤 & 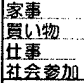 & 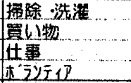 & & 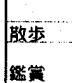 & 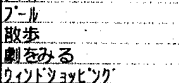 \\
\hline & |通䧣 & 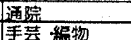 & & & 期溥会 \\
\hline & & 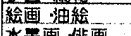 & & 琛集 & 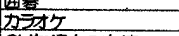 \\
\hline 污为 & 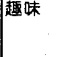 & 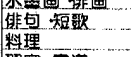 & 会話 交流 & 交流 & 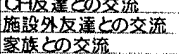 \\
\hline & & & & & \\
\hline
\end{tabular}

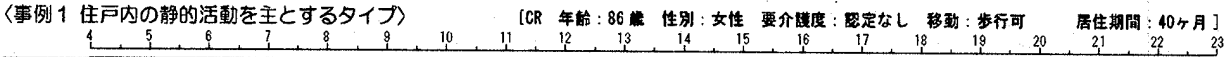

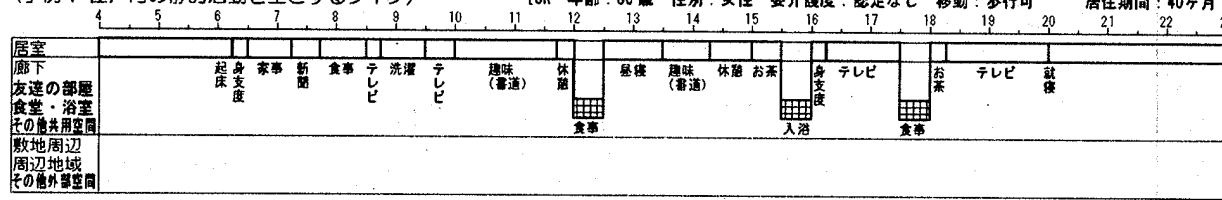

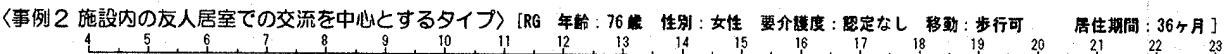

\begin{tabular}{|c|c|c|c|c|c|c|c|c|c|}
\hline & & 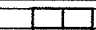 & 15 & $T$ & $T$ & 1 & 7 & & $T$ \\
\hline 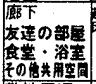 & 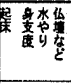 & 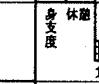 & 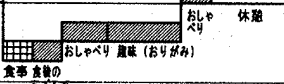 & 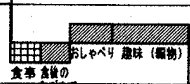 & 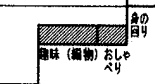 & 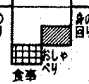 & 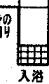 & 槽 & $\frac{1}{a_{z}}$ \\
\hline 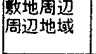 & & 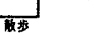 & The & trlek & 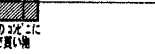 & & & & \\
\hline
\end{tabular}

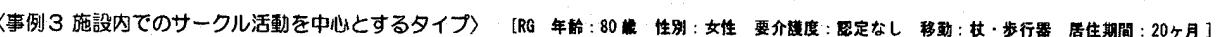

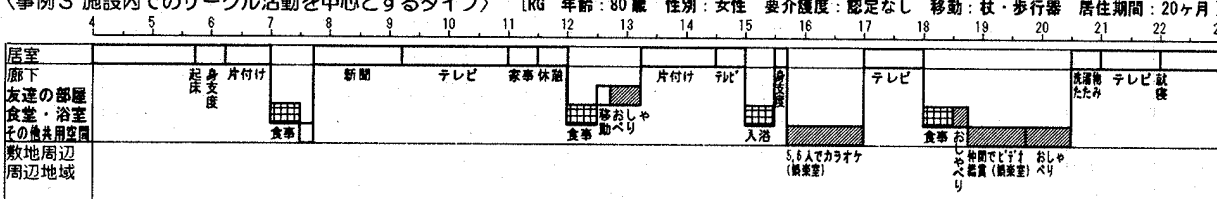

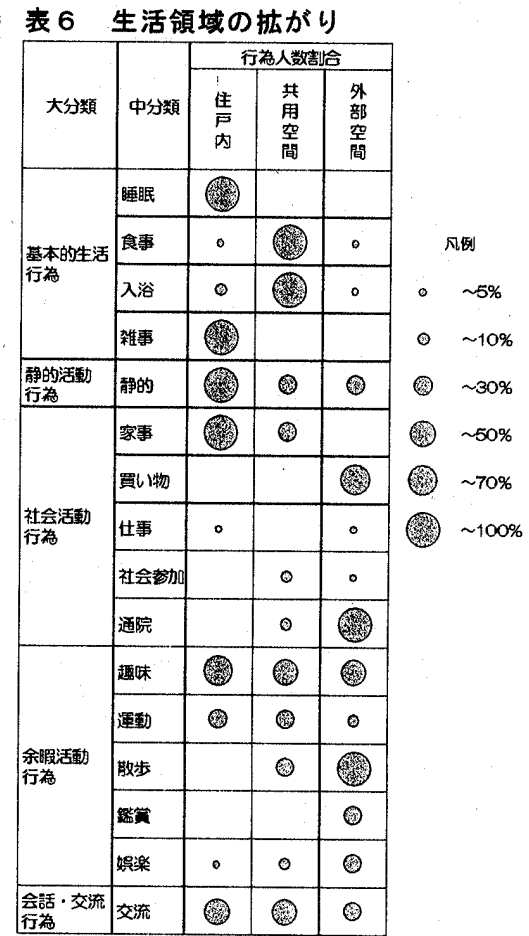

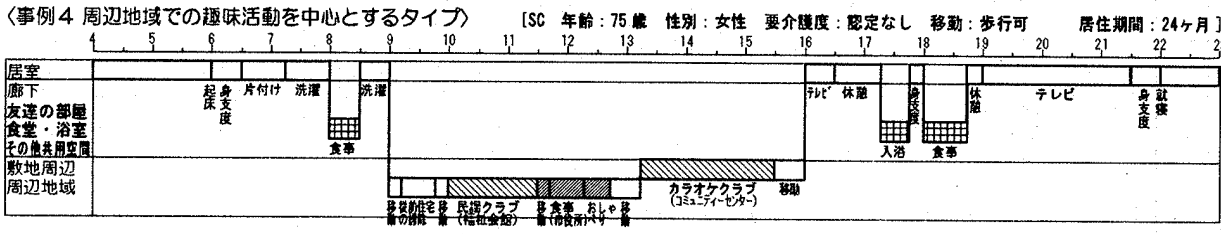

図 2 居住者 1 日の生活展開の事例 
と住戸構成を示す。ここでは住戸空間に着目し，そこで行われる生 活展開と所有寸る家具・物による住戸空間のしつらえについて明ら かにし，対応関係について考察する。

3. 1. 住戸内における生活展關調查(3より得られた 1 日の生活 時間のうち, 住戸内に滞在している時間の割合（住戸滞在率）を図 5 に示した。個人により滞在の割合は異なり，広い範囲で分布がみ られる。しかし，平均すると69\%程度（睡眠時間を加えた割合で は約 $80 \%$ ）と 1 日の大部分を住戸内で過ごしていることがわかる. ケアハウスにおける住戸空間の重要性が再確認される結果である といえる。住戸内で行われる行為の時間割合をみると， T V ・ 休眀を中心とした静的活動の割合が $45.6 \%$ と高く, 次いで基本的 生活行為, 社会活動行為となっている。余暇, 会話・交流行為は あわせて $5.7 \%$ 程度であるが，表 8 にられるとおり，頻度は高 くないものの行為の種類は多岐にわたっている。ケアハウスの住 戸は個人の活動の多様性を支える場として捉えることができる.

3. 2. 住戸内の家具の保有状況と家具密度 調査(4)より得られた データから, 主室の内法面積に対する床に置かれた家具の面積を 家具密度として計測し, 個々人について入居期間との関倸を示し たものが図 6 である．施設によっては入居時に持ち込む家具が制限 されることがあるなど, 入居当初の家具密度はあまり高くないもの の，入居期間が長くなるにつれ增加の傾向を示している．主室の 家具密度は, 平均で $30 \sim 40 \%$ と捉えることができるが, 最大で $60 \%$ に近い密度のもの[図 7 - 事例 2] もみられている. S CやC

\section{表 7 居室实測調查の概要と住戸構成}

\begin{tabular}{|c|c|c|c|c|}
\hline & & RG族設 & SC施設 & CR施設 \\
\hline & 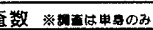 & 8 名 & 48 & 98 \\
\hline & 住巨面皘 & $300 \mathrm{~m}$ & $217 \mathrm{~m}$ & $218 \mathrm{~m}$ \\
\hline 售 & 主室面䅣 & $14.8 m^{2}(493 \%)$ & $103 \mathrm{~m}^{2}(475 \%)$ & $171 \mathrm{~m}(78.4 \%)$ \\
\hline$\vec{P}$ & 收納面積 & $69 \mathrm{~m}^{2}(230 \%)$ & $15 m^{2}(6.9 \%)$ & - \\
\hline 梅 & 浴室·卜化面皘 & $30 \mathrm{~m}^{2}(100 \%)$ & $37 \mathrm{~m}(17.1 \%)$ & $26 m^{\prime}(11.9 \%)$ \\
\hline & $11 \mu \mathrm{J}^{-}$-面栍 & $61 m^{2}$ & $67 \mathrm{~m}^{2}$ & $=$ \\
\hline
\end{tabular}

\begin{tabular}{|c|c|}
\hline $\begin{array}{l}\text { 事例1 RG3 } \\
\text { 年秢 : 90葴 }\end{array}$ & $\begin{array}{l}\text { 事例 } 2 \mathrm{SC7} \\
\text { 年数 }: 85 \text { 歲 }\end{array}$ \\
\hline 性別：女性 & 性別：男性 \\
\hline 居住期間：11ヶ月 & 居住期間 : 41? \\
\hline 家貝密度 : $41.9 \%$ & 家具密度: $57.8 \%$ \\
\hline 滞在率 $: 85.4 \%$ & 滞在率 : $76.0 \%$ \\
\hline
\end{tabular}
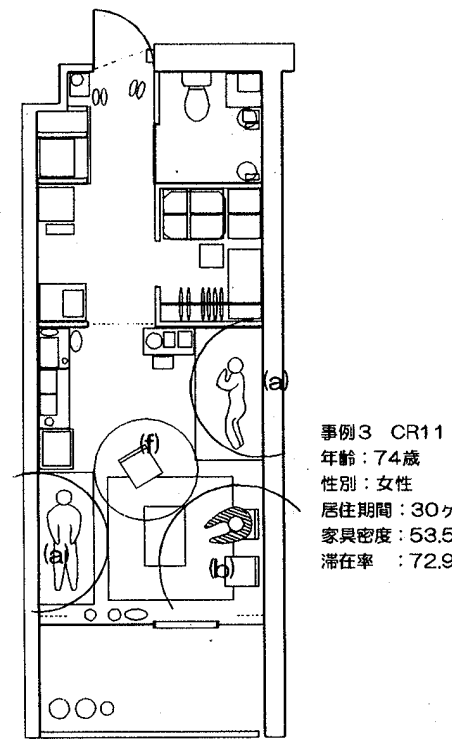

年粭: 74 嵗 性別: 女性 居住期間：30ケ月 家具密度 : $53.5 \%$ 滞在率 $: 72.9 \%$

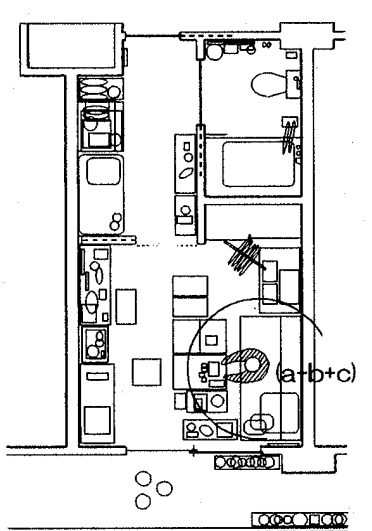

図 7 住戸内のしつらえと場の形成事例
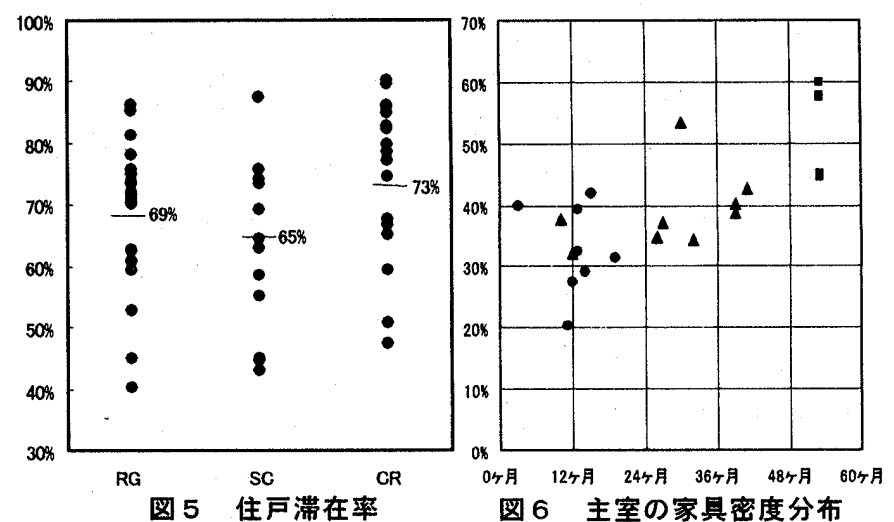

表 8 住戸内で行われる行為

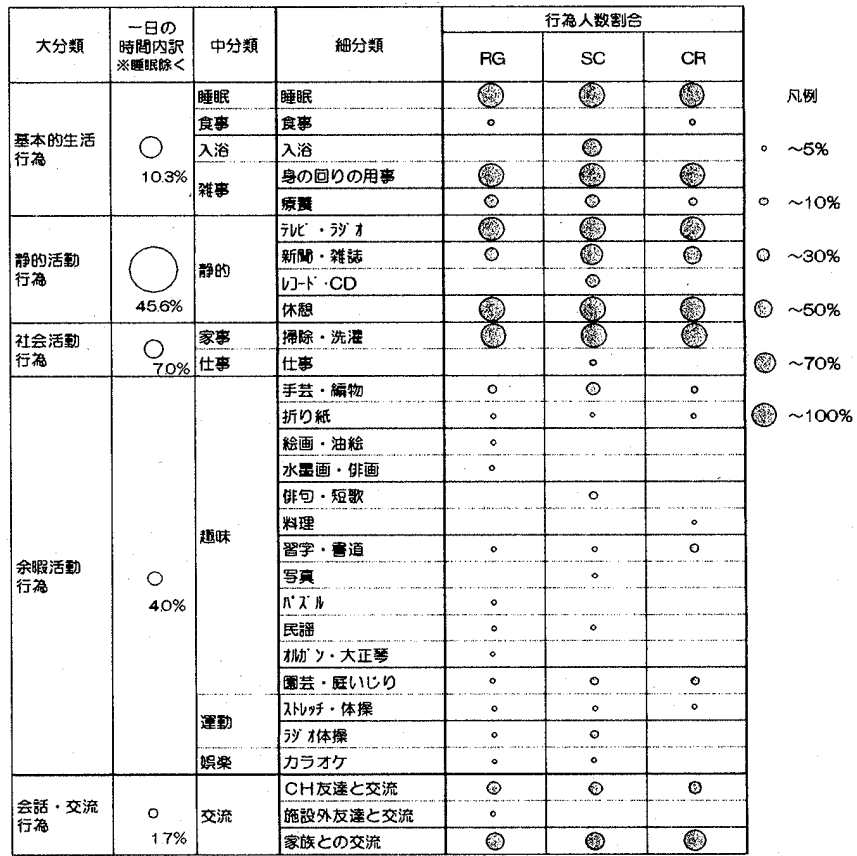

主户内 合部 $68.6 \%$

表 9 住戸内に形成される場の分類

\begin{tabular}{|c|c|c|c|}
\hline 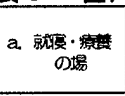 & 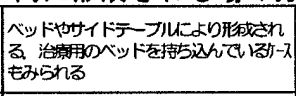 & 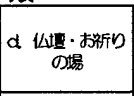 & 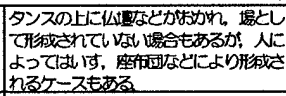 \\
\hline b. TV.新周 & 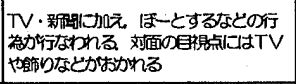 & 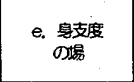 & 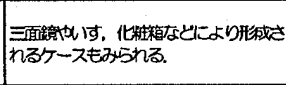 \\
\hline $\begin{array}{l}\text { c. 趣枺・教 } \\
\text { の揚 }\end{array}$ & 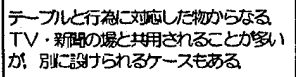 & $\begin{array}{l}\text { f. 友人.客人 } \\
\text { の埸 }\end{array}$ & 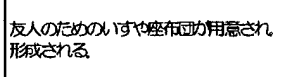 \\
\hline
\end{tabular}

\section{表 10 場の形成事例}

\begin{tabular}{|c|c|c|c|c|c|c|c|c|}
\hline 施設 & 番骂 & 属性 & 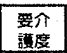 & 冢具密度 & 住間内で行なわれる行為 & 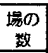 & \begin{tabular}{|l|} 
塄の \\
重犦 \\
\end{tabular} & 場の形成の状況 \\
\hline \multirow{5}{*}{$R G$} & 1 & 84 嵅 & なL & $27.4 \%$ & TV，新䦦，休筧 & 2 & 0 & (a), (b) \\
\hline & 2 & 81 䧕 & TLL & $29.2 \%$ & TV，䛃急。休憩 & 2 & 0 & (a), (b) \\
\hline & 3 & 90 诚 & SL & $41.9 \%$ & 交流，TV，新䦦，票票 & 4 & $\mathrm{O}$ & $(a),(a),(b),(f)$ \\
\hline & 4 & 64 茛 & なL & $20.3 \%$ & TV, 休秝 & 3 & 0 & $(a),(b),(b)$ \\
\hline & 5 & 81 荿 & な2 & $40.0 \%$ & 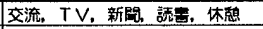 & 2 & 1 & $(a),(b),(f)$ \\
\hline \multirow{4}{*}{ sc } & 6 & 83 被 & 要支援 & $59.9 \%$ & 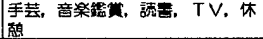 & 2 & 1 & $(a),(b+c)$ \\
\hline & 7 & 85 稢 & なし & $57.8 \%$ & 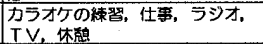 & 1 & 2 & $(a+b+c)$ \\
\hline & 8 & 87 荿 & 要支援 & $44.6 \%$ & 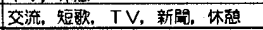 & 2 & 1 & (a). $(b+c+f)$ \\
\hline & $\overline{9}$ & 76 致 & なし & $45.2 \%$ & CD，TV，休鳘，身支度，体操 & 3 & o & $(a),(b+c),(e)$ \\
\hline \multirow{5}{*}{$\mathrm{CR}$} & 10 & 83 离 & 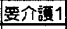 & $37.6 \%$ & 交流， お祈り，TV，休猶，体操 & 3 & $\underline{0}$ & $(a),(b+d),(f)$ \\
\hline & 11 & 74 成 & 嬛支援 & $53.5 \%$ & 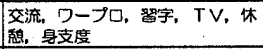 & 4 & 1 & $(a),(b),(c),(e+f)$ \\
\hline & 12 & 80 或 & 㩊介愲 & $32.1 \%$ & 交流，䛨管，TV，休照，体操 & 3 & $\mathrm{O}$ & $(a),(b),(f)$ \\
\hline & 13 & 83 㵝 & なㄴ & $37.1 \%$ & 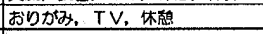 & 2 & 1 & $(a) \cdot(b+c)$ \\
\hline & 14 & 72 証 & 要支援 & $42.6 \%$ & 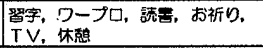 & 3 & 1 & $(a),(b+c),(d)$ \\
\hline
\end{tabular}


$\mathrm{R}$ 施設では収納スペースが少ないことから[図 7 - 事例 $2 ， 3]$ のよ うに，主室の一画に収納場所が設けられ，家具密度が高くなるケー スがみられた。

3.3. 行為に対応した場の形成 居住者は家具や所有物により，住 戸内で行われる行為に対応した場をしつらえている，特定の行為を 行う場所が安定的に確保されていることを基準に，住戸内に形成さ れる場を 6 種類に分類することができた（表 9)。場の形成が明確 に認識できる 14 事例について表 10 に示し，その形成状況について 特徽をあげると以下の通りとなる，1）住戸内に形成される場の 数は1 から4である. 2) 家具密度が高くなると場の形成が難し くなり，幾つかの場が重複して形成される傾向がみられる $(5,6,7,8,11,14)$. [図 7 ・事例 2] の上うに3つの場が重複される 例もみられる。 3 ） b と c の場が重複され形成されるケース $(6,7,8,9,13,14)$ が多くみうけられたが、[図 7・事例 3]のように 主室にスペースがあることにより，別々に設けることが可能とな る.4)[図 7・事例 1]のように療養の場としてベッドを持ち込 み a の場を $2 つ$ 形成するようなケースむみられた。このように，住 戸内の活動の様態や個人の属性に対応し，幾つかの場を重複させた り，同じ場を幾つか設けたりすることにより空閒を有勃に利用して いるが, 住戸内の場は住戸の広さや家具密度との関係により形成さ れるといえる.

\section{4. 共用空間の使われ方}

4.1. 共用空間における生活展開 1 日における共用空間の滞在時 間は $18 〜 24 \%$ となっているが，プログラム活動拄3〉がそのうちの 6 割程度を占め，4割程度が入居者によるサ一クル注4) および自由
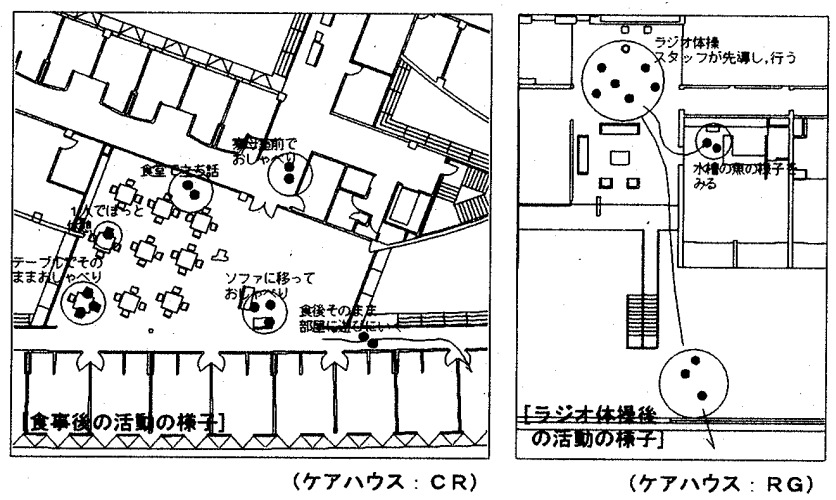

図10 プログラム前後の活動の様子
活動場面となる（図 8）。共用空間で行われる行為をみると，食事・ 入浴はほとんどの居住者が行い（S C 施設の入浴は約半数が自室), 共用空間で行なわれる活動の中心になっている。その他では, ケア ハウス内の友達との会話交流が多く，また，施設内での散歩や休憩 なども行われている．趣味娛楽はサークル活動として行われている， ものがほとんどであり，行為の種類は住戸空間や外部空間で行える 行為の種類に比べてあまり多くない（表１１）。

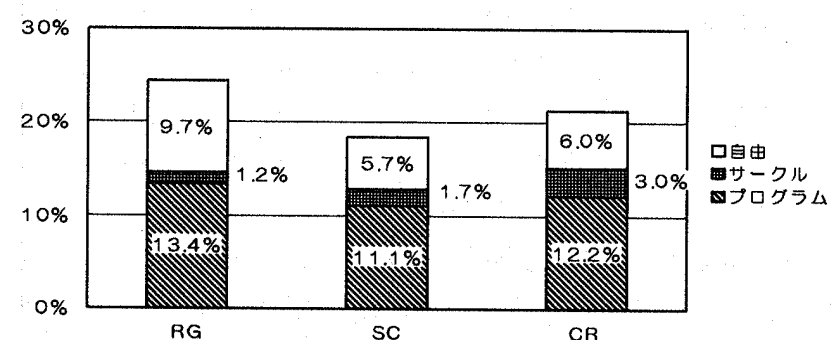

図 8 共用空間滞在率内訳（睡眠除く）

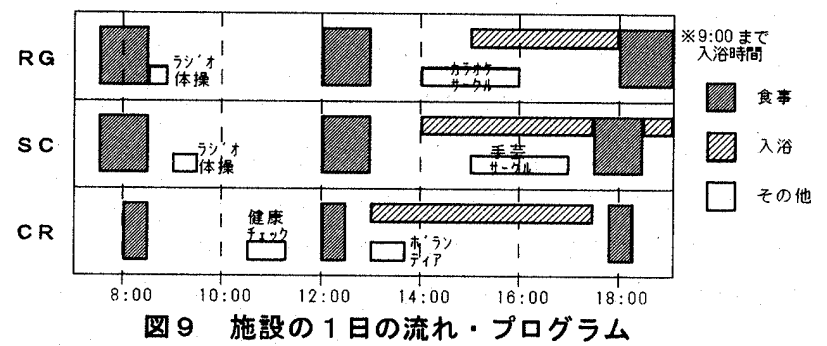

表 11 共用空間で行われる行為

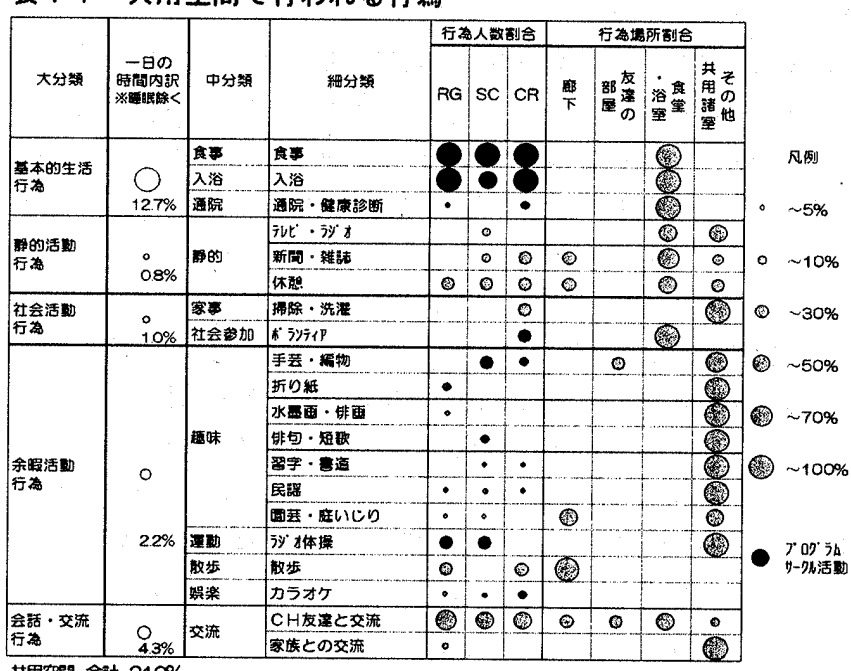

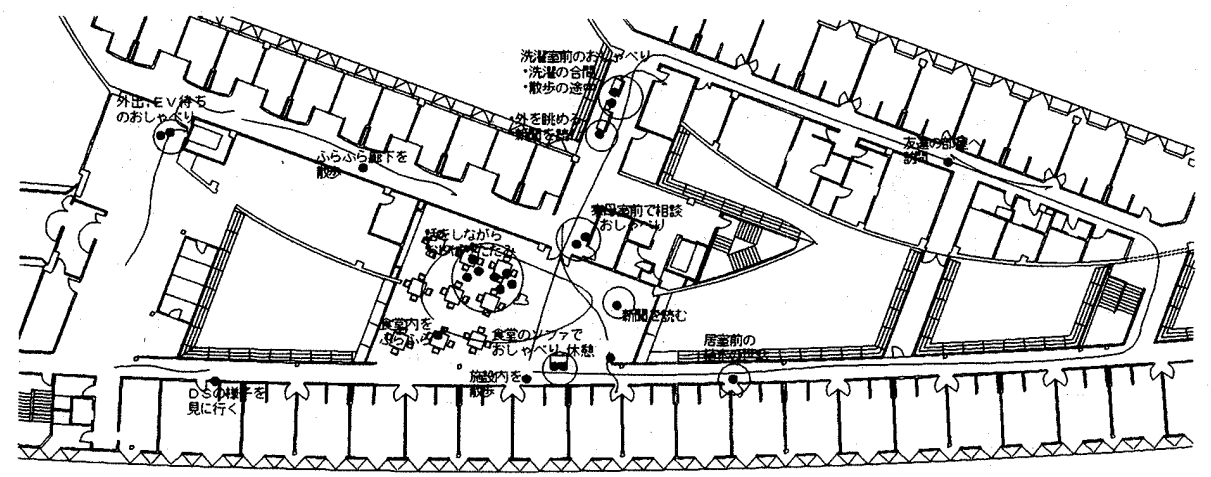

图 11 自由時間の活動の様子 (ケアハウス: CR)

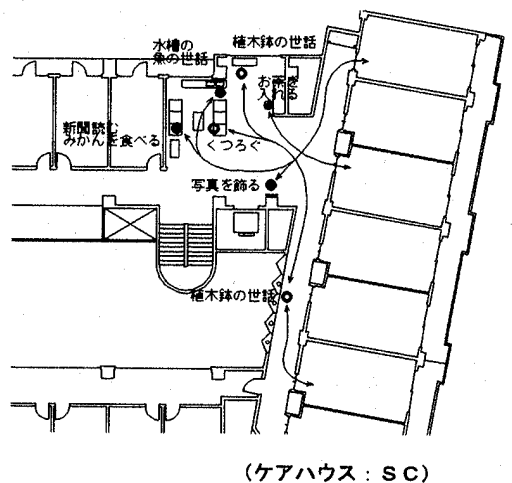

図 12 共用空間と居室の関係 


\section{2. プログラム・サークルおよびその前後における生活展開の様子} 調査(2)より，共用空間において観察された生活展開の様子を，プ ログラム・サークル時間と自由時間に分けてみていく。

ケアハウスにおける 1 日の流れは，概ね全員が参加する食事・入 浴の活動と入居者が選択して参加するサークル活動の時間帯, およ び，その間に行われる自由時間により成る（図 9）。プログラム時 間にあわせ入居者は集合と離散を繰り返し行うが, その集合と離散 の間に交流活動が多く行われ，いくつかグループが形成される様態 が観察された。 さらに, そこから他の場所に移り活動が展開される 様子もみられた（図 10 ）。このように，プログラム時間はそれだ けの活動としてだけでなく，人が集まることにより行為を展開して いく可能性をもっていることが確認できた。

4. 3. 自由時間における生活展開の様子自由行動は施設内の友達 との交流や散歩, 又はそれらに伴う休鄎が中心である。交流や休䕀 は散歩や外出又はプログラム場面からの移動の動線上にある廊下や オープンに設けられている空間のコーナーやソファで多く観察され る. 反面, 居室群の端にあるコーナーの利用はほとんどみられない. 各施設とも娛楽室等の共用諸室が設けられているが，壁で囲まれ閉 じた共用諸室はサークル活動以外では利用されにくい傾向がある.

また，身体に不安のある高㱓者が廊下で散歩を行う場面は, 長い 廊下がある施設にみられる特徴的な行為であり，このような廊下空 間は歩行訓練のための一種のリハビリテーション空間としての機能 を果たしているとみることもでき, 自立生活を支える空間として重 要であると考えられる. (図 11 1).

居室との関係で共用空間の利用状況をみると（図 12 ), 住戸に 近い共用空間を, くつろぐ, お茶, 新聞など居間的に利用する行為 や自室前の廊下空間を飾りつける, 動植物の世話をする行為など, 一般に私的な空間で行われるような行為が隣接する共用空間で行わ れる様子がみられた。

\section{5. 外部空間の使われ方}

5.1. 外部空間における生活展開 1 日における外出行動の時間割 合は平均すると $9 \%$ （睡眠時間を加えた割合では $6 \%$ ）と多くな いが，1人 1 人についてみてみると，多いもので $45 \%$ の時間を施設 外で過ごす人もみられ，個々人の行動タイプによって様々である。
同様に， 1 週間における外出件数の分布（図 13 ）をみると，外部 空間の使われ方は一様ではなく，個人による差がかなりみられる結 果となっている，また，施設別にも頻度の状況が異なり， S C施設 では 10.3 件／週と高いのに対し，CR施設では 3.7 件／週と極端 に低くなっている，S C 施設は敷地周辺に行為を行える場所が多く

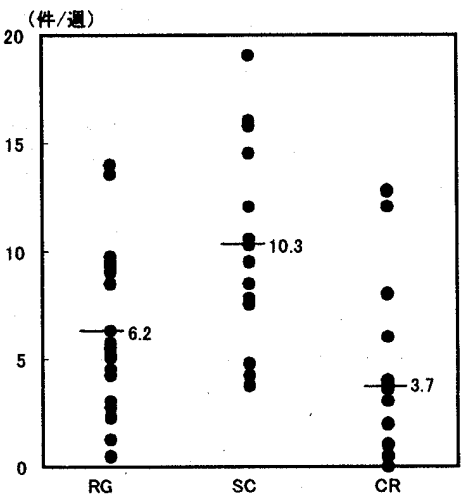

図13 施設別の外出件数分布

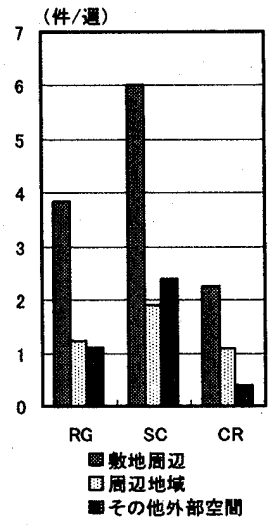

図 14 施設別の圈域別 平均外出件数

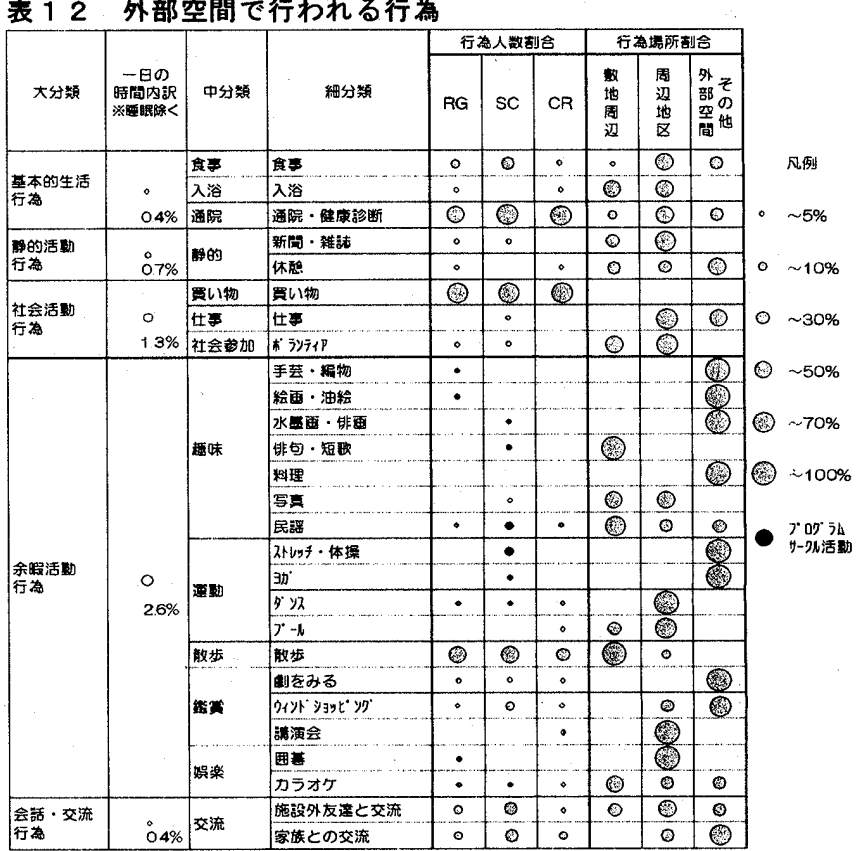

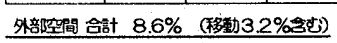

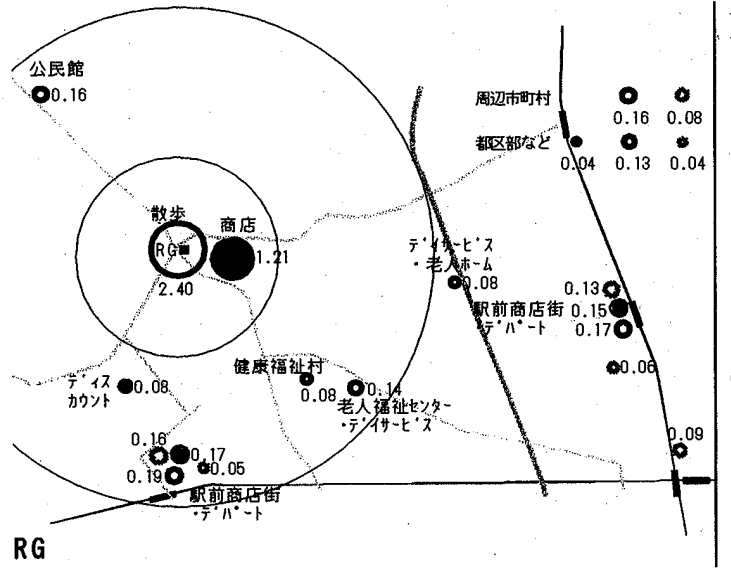

図 15 活動圈域と利用施設
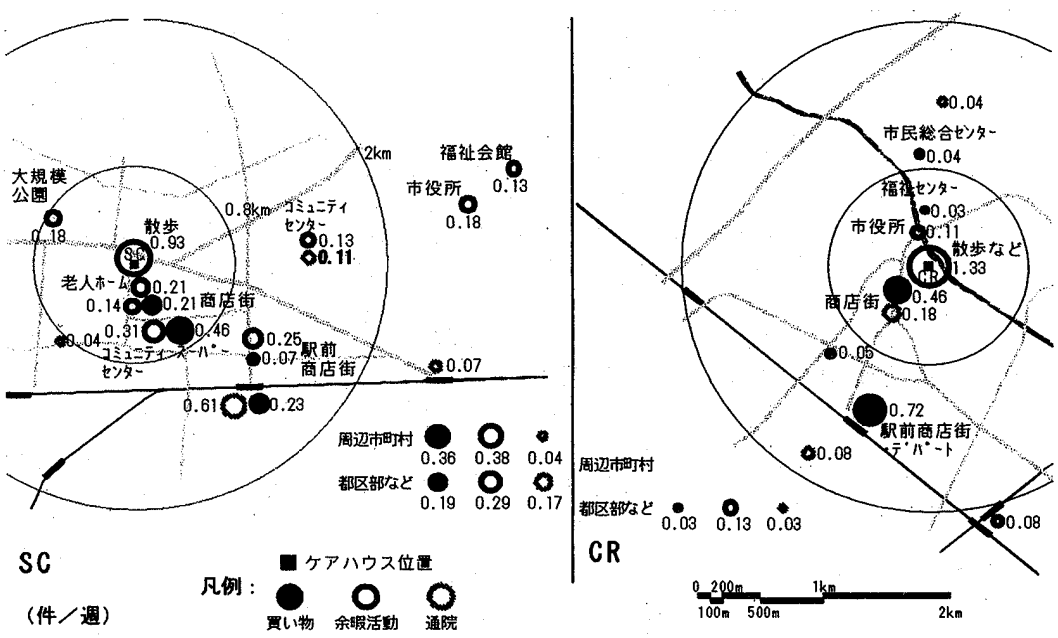
みられ，その影響から教地周辺における外出頻度が高くなっている と考えられる (図 14 ). 前述した加跉による外出活動の減少とは別 に，施設内外の地域環境が影響しているものと思われる。

外部空間で行われる行為（表 12 ）をみると，買い物，散歩，通 院・健康䛦断が上位を占める。それ以外の行為も頻度は低いものの， 外部空間において多様な行為が展開されていることがわかる.

5. 2. 活動圆域之利用施設 外部空閒における圈域の拡がりは，各 行為種類により異なる様相がみられる（図 15 )。 それぞれの行為を みていくと，蕒い物では主に教地周辺における商店やスーパーで行 われる. RG 施設では敷地周辺にある商店に外出件数が集中寸るな ど, 外部空間の構成により空間の拡がりの様相が異なる，周辺地区 外一の買い物もみられたが，これも交通利便性の高いS C 施設で多 くみられるなど立地環境により傾向が左右される。趣味娛楽行為は 散歩を除いては，それぞれ行為人数が少ないが様々な種類の行為が みられる。これらの行為の利用施設は，公民館，コミュニティーセ ンター, 福祉センター, デイサービスセンターなど地域のコミュニ ティー施設において行われ，多くは講座やサークルでの活動と考え られる．周辺地区にかかわらず，広域的な範囲での展開がみられて おり，個々人の属性や好みにより選択が行われているものと思われ る. 散歩は敫地周辺で行われ，行為人数割合が高く，日常的な行為 といえる，共用空間の廊下とを使い分け行われている．外出行動は ほとんど行わないが，散歩だけは行うといった居住者も多くみられ る. 病院・健康診断は半数程度の行為人数の割合がみられる. 数地 周辺の診療所等で行われる割合は少なく，比較的大きな病院への通 院が多くみられ，広い範囲へ展開されることが特徵である。

\section{6. 拡がりからみた各行為の分類と性格}

前段において各空間ごとに行われる行為についての把握を行って きたが，ここでは，各行為における空閒の拡がりの特性に着目し， 行為の分類を行っている（表 13 ）。

〈特定性〉特定の空間でのみ行われる行為であり，空間の拡がりはみ られない。

〈施設選択性〉外部空閒において施設や場所を選択して行う行為であ り，外部空間の施設環境などが空間の拡がりに大きく影響を及ぼす。 行為の種類によっては, 個々人の属性にあった選択が行えないこと により行為が行われなくなるなど，いわゆる行為の潜在化がおこる 可能性を持つ。

〈空間選択性〉自室内，共用空間，外部空間においてて, 入居者個人の 状况や好みにあわせ，空間を選択して行う行為であり，〈施設選択 性〉と同様の性格を持つ。

〈展開性〉他の空間で行われる活動と関連し，場所を移し異なる様態 の行為として展開されるものである. 例えば外部空間の施設で行っ たサークル活動に関連し，自室内でその活動を行うようなことがあ てはまる。各空間に連動して拡がっていく性格を持つ。

〈付属性〉他の行為に付帯し，様々な空間において行われる行為であ り，他の行為の拡がりと関連し，同様の広がりの様態を表す。

\section{7. まとめ}

以上から，ケアハウス居住者の生活展開と生活領域の拡がりに関
して得られた知見について述べる。

(1)住戸空間での活動は多様であり，それらの活動にあわせ幾つかの 場が形成されることがわかった。また，それらの場の形成は，持ち 込まれる家具などとの関係により難しくなることも考えられるため, 場の形成の様態に対応した住戸空閒の充実が必要と考えられる。 (2)共用空間における活動は，廊下やオープンな空間のコーナやソ ファが重要な役割を果たしていることがわかった。しかしながら， 単に場所を設けるのではなく散歩や外出又はプログラム活動への移 動など，共用空間における生活展開の様態にあわせた空間の構成が 必要と考えられる。

(3)外部空閒での活動は居住者が各施設や場を選択して行われ，それ らの行動は立地環境により，大きく影響をうけることがわかった。 (4)居住者の中には，加齢とともに身体能力が低下し，共用空間と自 室での活動が主となる人もいるため，外部空間で行われる活動の幾 つかについては共用空閒で対応していくことも課題として捉えるこ とができる。

(5)各行為ごとに領域の拡がりの特性は異なり，段階性，選択性，展 開性, 付属性がみられる. それらの様態により各行為を分類するこ とができた。これら各行為の桩がりの特性にあわせた空間の構成が が求められる。

\section{表 13 生活領域の拡がりからみた行為分類}

\begin{tabular}{|c|c|c|c|c|c|}
\hline 行為分類 & 定乘 & 住所内 & 共用空間 & 外部空四 & 行染棰粸 \\
\hline \multirow{2}{*}{$\begin{array}{l}\text { 空䧄特定型 } \\
\text { 行学 }\end{array}$} & \multirow{2}{*}{$\begin{array}{l}\text { 特定の祭娄において行われる } \\
\text { 活舫 } \\
\text { (特定性) }\end{array}$} & & & & 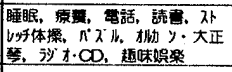 \\
\hline & & & & & 䀶事（日坣的なもの） \\
\hline 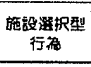 & 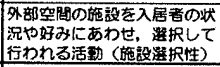 & & & & 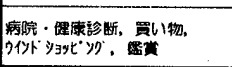 \\
\hline \multirow{3}{*}{ 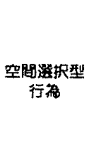 } & \multirow{3}{*}{ 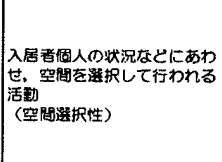 } & & & & 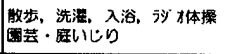 \\
\hline & & & & & 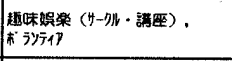 \\
\hline & & & & & 嫁族との交流 \\
\hline \multirow{2}{*}{$\begin{array}{l}\text { 閧閏型 } \\
\text { 行諼 }\end{array}$} & \multirow{2}{*}{ 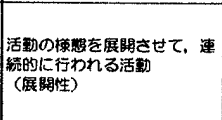 } & & & & 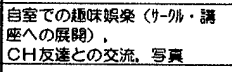 \\
\hline & & & & & $\begin{array}{l}\text { 外期空間てのCH友達との交 } \\
\text { 流 }\end{array}$ \\
\hline $\begin{array}{l}\text { 付堣㷱 } \\
\text { 行為 }\end{array}$ & 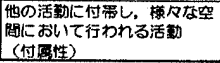 & & & & 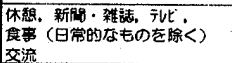 \\
\hline
\end{tabular}

謝辞

末筆ながら調査にご協力頂きました各施設の入居者の皆様とス タッフのカ々にお礼を申し上げます。 
注釈

1） 1 日の時間内訳は睡眠時間を除いた内訳として表している。

（図3，図4，表 $8 ，$ 表11）

2) 行為人数割合は， 1 週間の活動においてみられた人数の割合(延べでは

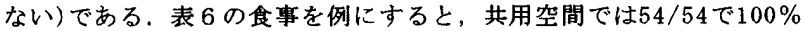

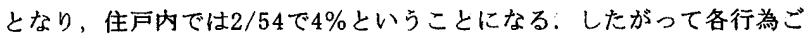
との割合は $100 \%$ にならない，行為場所割合は，各行為の頻度を場所別 の割合として表している。このため，合計は100\%である。

(表6，8，11，12)

3）プログラム活動とは，食事，入浴，ラジオ体操などの施設側から提供さ れるメニューを指す。

4） サークル活動は，ボランティア，レクリエーションの活動であり，入居 者が自発的に参加するものである。外部空間においては講座やレクリエ ーション等の教室も含む.
参考文献

1）小川正光他:ケアハウスの施設計画と入居者の実態 その $1 \sim 3$, 日本 建築学会大会学術講演梗概集, pp. 5-10, 1995

2）森氷光典他:ケアハウスの生活拠点移動(リロケーション)に関する研 究，日本建筮学会大会学術講演梗概集，pp. 231-234，1996

3）野村梅, 高山忠雄編: 長寿社会総合講座 6 高榆者の住噮境, 第一法規 出版, 1993. 12

4） N H K 放送文化研究所: 現代日本人の意識構造第 4版, NH Kブックス 1998

5）伊佐地大輔他: ケアハウス居住者の生活展開と行為空間の広がりに関す る研究・その $1 \sim 2$, 日本建築学会大会学術講演梗概集, 2001

(2001年 9 月 5 日原稿受理，2002年 3 月 25 日採用決定） 